\title{
AKTIFITAS ANTIINFLAMASI FRAKSI-FRAKSI EKSTRAK ETANOL 95\% DARI DAUN KERSEN (Muntingia Calabura L.) PADA TIKUS PUTIH JANTAN
}

\section{ANTIINFLAMATORY ACTIVITY OF 95\% ETHANOL EXTRACT FRACTION OF KERSEN LEAVES (Muntingia calabura L.) IN THE MALE WHITE RAT}

\author{
Maifitrianti, Landyyun Rahmawan Sjahid, Nuroh, Rizqa Ayutri Muyus Acepa, Widya Dwi \\ Murti
}

Faculty of Pharmacy, Universitas Muhammadiyah Prof. Dr. Hamka, Islamic Center, JI. Delima II/IV, Klender, Jakarta Timur, Indonesia

Email: maifitrianti@uhamka.ac.id (Maifitrianti)

\begin{abstract}
ABSTRAK
Ekstrak etanol daun kersen (Muntingia calabura L.) telah lama digunakan sebagai tanaman obat. Penelitian ini bertujuan untuk mengetahui fraksi dari ekstrak etanol daun kersen yang memiliki efek antiinflamasi melalui parameter penurunan volume eksudat, penurunan jumlah leukosit, monosit, neutrofil, dan limfosit eksudat pada tikus putih jantan udem yang diinduksi karagenin. Hewan percobaan dibagi menjadi lima kelompok yaitu kelompok I (kontrol negatif diberi $\mathrm{Na} C \mathrm{CMC} 0,5 \%$ ), kelompok II (kontrol positif diberi natrium diklofenak $10,278 \mathrm{mg} / \mathrm{kgBB}$ ), kelompok III, IV, dan V diberi fraksi $n$-heksana, fraksi etil asetat, dan fraksi air masing-masing dengan dosis $5,15 \mathrm{mg} / \mathrm{kgBB}$. Metode yang digunakan adalah metode kantung granuloma (granuloma pouch). Udem pada tikus diinduksi dengan menyuntikkan karagenin $2 \%$ secara subkutan. Suspensi fraksi diberikan secara oral, satu jam sebelum induksi udem. Volume eksudat, jumlah leukosit, monosit, neutrofil, dan limfosit eksudat diukur setelah 24 jam. Data yang didapat diuji secara statistik dengan one-way ANOVA yang dilanjutkan dengan uji Tukey. Hasil penelitian menunjukkan bahwa fraksi etil asetat dengan dosis $5,15 \mathrm{mg} / \mathrm{kgBB}$ tikus dapat menurunkan volume eksudat dan jumlah leukosit eksudat secara signifikan $(p<0,05)$. Efek antiinflamasi fraksi ini juga sebanding dengan kontrol positif yaitu natrium diklofenak dengan dosis $10,278 \mathrm{mg} / \mathrm{kgBB}$ tikus.
\end{abstract}

Kata kunci: antiinflamasi, fraksi, kersen (Muntingia calabura L.), udem.

\begin{abstract}
Ethanol extract of kersen (Muntingia calabura L.) leaves has long been used as a medicinal plant. This study aimed to determine the anti-inflammatory properties of fractions of ethanol extract of calabur leaves evaluated through the parameters of decreasing volume of exudates and the number of leukocytes, monocytes, neutrophils and lymphocytes in the exudates of male white rats induced by carrageenan. The experimental animals were divided into five groups: group I (negative control group,
\end{abstract}


given with $0.5 \% \mathrm{NaCMC}$ ), group II (positive control group, treated with sodium diclofenac at a dose of $10.278 \mathrm{mg} / \mathrm{kg}$ rat body weight), as well as group III, IV, and V that were treated with n-hexane, ethyl acetate, and water fractions of ethanol extract of calabur leaves at the doses of $5.13 \mathrm{mg} / \mathrm{kg}$ rat body weight, respectively. The granuloma pouch method was used, which the edema in rats was induced by injecting $2 \%$ carrageenan subcutaneously. The fractions were given orally one hour before the induction of edema. The volume of exudates, as well as the number of leukocytes, monocytes, neutrophils, and lymphocytes in the exudates, were measured after 24 hours. The data was statistically tested using one-way ANOVA followed by the Tukey test. The results showed that ethyl acetate fraction at a dose of $5.13 \mathrm{mg} / \mathrm{kg}$ rat body weight reduced the volume of exudate and the number of leukocytes in the exudates significantly $(p<0.05)$. The antiinflammatory effect of this fraction was comparable to that of the sodium diclofenac at a dose of $10.28 \mathrm{mg} / \mathrm{kg}$ rat body weight.

Key words: calabur (Muntingia calabura L.), fractions, edema, anti-inflammatory. 


\section{Pendahuluan}

Inflamasi merupakan suatu respon protektif normal terhadap luka jaringan yang disebabkan oleh trauma fisik, zat kimia yang merusak, atau zat mikrobiologi. Inflamasi biasanya terbagi dalam tiga fase yaitu inflamasi akut, respon imun, dan inflamasi kronis. Inflamasi akut merupakan respon awal terhadap cedera jaringan melalui rilisnya autacoid yang terlibat antara lain histamin, serotonin, bradikinin, prostaglandin, dan leukotrien. Respon imun terjadi bila sejumlah sel yang mampu menimbulkan kekebalan diaktifkan untuk merespon organisme asing atau substansi antigenik yang terlepas selama respon terhadap inflamasi akut serta kronis. Akibat respon imun bagi tuan rumah mungkin menguntungkan, misalnya menyebabkan organisme penyerang difagositosis atau dinetralisir. Sebaliknya akibat tersebut juga dapat bersifat merusak bila menjurus pada inflamasi kronis tanpa penguraian dari proses cedera yang mendasarinya. Inflamasi kronis menyebabkan keluarnya sejumlah mediator yang tidak menonjol dalam respon akut. Salah satu kondisi yang paling penting yang melibatkan mediator ini adalah artritis rheumatoid. Penyakit inflamasi kronis seperti artritis rhematoid ini masih merupakan salah satu masalah kesehatan utama bagi masyarakat di seluruh dunia (Furst et al., 2013).

Obat golongan NSAID (Non Steroid Antiinflammatory drug) dan kortikosteroid merupakan obat yang digunakan untuk mengatasi inflamasi. Namun penggunaan NSAID jangka panjang dapat menyebabkan berbagai efek samping seperti tukak dan pendarahan saluran cerna, nefrotoksik, serta hepatotoksik. Steroid dapat menekan sistem kekebalan tubuh dan memicu disfungsi ereksi, manic depression, hipertensi, kram dan pusing, munculnya diabetes aktif, atrofi kulit, penurunan kepadatan tulang, sakit maag dengan kemungkinan perforasi dinding lambung, menstruasi tidak teratur, penglihatan dan masalah alergi, serta mengurangi penyembuhan luka (Furst et al., 2013). Oleh karena itu perlu dilakukan berbagai penelitian untuk mengembangkan obat antiinflamasi baru dengan efek samping minimum.

Muntingia calabura L. atau dikenal dengan nama kersen merupakan tanaman berbunga yang termasuk keluarga Elaocarpaceae. Tanaman ini merupakan pohon berbuah yang bahkan 
dapat tumbuh baik, di tanah yang kurang subur dan mampu mentolerir kondisi asam, basa, serta kekeringan. Daun kersen memiliki efek sebagai kardioprotektif, antipiretik, antioksidan, antiinflamasi, antidiabetes, antibakteri, dan antiulcer (Mahmood, 2014). Selain itu kersen juga memiliki efek farmakologi sebagai antiplatelet dan aktifitas sitotoksik. Kersen memiliki kandungan flavonoid, saponin, dan tanin. Flavonoid yang terkandung di dalam kersen adalah flavon, flavanon, flavan, dan biflavan. Flavonoid banyak mendapat perhatian karena kelompok senyawa ini memiliki aktivitas seperti antibakteri, antiinflamasi, dan antioksidan (Kuo et al., 2014).

Sarimanah et al. (2015) menyimpulkan bahwa ekstrak etanol 95\% daun kersen pada dosis 50 mg/kgBB dan $100 \mathrm{mg} / \mathrm{kgBB}$ menunjukkan efek antiinflamasi dengan persentase hambatan inflamasi sebesar 58,33\% dan $52,78 \%$. Selain itu penelitian yang dilakukan oleh Nurdin et al. (2016) menyimpulkan bahwa ekstrak daun kersen dengan konsentrasi 2,5; 5, dan 10\% memiliki aktivitas inflamasi topikal.

\section{Berdasarkan latar belakang} tersebut perlu dilakukan penelitian lebih lanjut untuk memperoleh kelompok senyawa yang lebih spesifik dan diharapkan dapat mengarahkan pada informasi fraksi dengan kelompok senyawa yang diduga aktif sebagai antiinflamasi. Oleh karena itu, pada penelitian ini dilakukan uji aktivitas antiinflamasi fraksi dari ekstrak etanol 95\% daun kersen pada tikus putih jantan melalui parameter penurunan volume eksudat dan penurunan jumlah leukosit eksudat pada tikus putih jantan udem yang diinduksi karagenin. Fraksinasi bertujuan untuk memisahkan kelompok senyawa aktif secara spesifik berdasarkan tingkat kepolarannya (kurang polar, semi polar, dan polar).

\section{Metode Penelitian}

Alat dan Bahan

Alat-alat yang digunakan dalam penelitian yaitu: timbangan analitik (Ohaus), syringe filter steril (Nylon), corong pisah (Duran), corong kaca (Pyrex), spuit (Terumo), vacuum rotary evaporator (Eyela), oven (Memmert), UV Box (Camag), mikroskop (Novel), krus, sarung tangan, kamar hitung leukosit (Improved Neubauer), tanur, sonde, syringe (Terumo) 20, 10, dan $5 \mathrm{ml}$, needle (Terumo) 23 G, 20 G, 18 G, object glass, cover gelas, mikropor (Nexcare), tempat makan dan minum tikus, serta 
alat-alat gelas yang umum digunakan di laboratorium.

Daun kersen diperoleh dari Badan Penelitian Tanaman Rempah dan Obat (Balitro) dan dideterminasi di Herbarium Bogoriense LIPI Cibinong, Bogor. Pelarut untuk ekstraksi dan fraksinasi yang digunakan antara lain etanol 95\%, akuades, $n$-heksana, dan etil asetat. Karagenin (Sigma) sebagai peginduksi. Na diklofenak (Kimia Farma) sebagai pembanding. $\mathrm{NaCl}$ fisiologis (Widatra Bhakti) sebagai pelarut. Pewarna giemsa (Himedia) untuk pewarnaan. Ketamin (Combiphar) sebagai agen anestesi. Krim pencukur bulu (Veet) untuk menghilangkan bulu pada punggung tikus. Fase diam yang digunakan adalah silika gel $\mathrm{GF}_{254}$ (Merck). Eluen yang digunakan adalah nheksana, etil asetat, kloroform, dan metanol. Pereaksi yang digunakan untuk penapisan fitokimia terdiri dari pereaksi semprot vanilin-asam sulfat, Dragendorff, sitroborat, ferri klorida, Liebermann-Bouchard. Natrium carboxymethy cellulose sodium (Na CMC) sebagai pensuspensi fraksi. Larutan phospat buffered saline (PBS) sebagai larutan buffer.

\section{Jalannya Penelitian}

1. Pembuatan serbuk simplisia daun kersen

Pembuatan simplisia daun menggunakan daun kersen yang sudah tua. Sebanyak $1,5 \mathrm{~kg}$ daun kersen dipotong-potong dan dikeringkan dengan cara dianginanginkan tanpa sinar matahari langsung. Daun kersen yang sudah kering kemudian diblender dan diayak dengan ayakan no mesh 40 , selanjutnya ditimbang.

2. Pembuatan ekstrak etanol $95 \%$ daun kersen

Serbuk daun kersen dimaserasi dengan pelarut etanol $95 \%$ sampai serbuk terendam. Proses maserasi dilakukan selama 6 jam pertama sambil sekali-sekali diaduk, kemudian didiamkan selama 24 jam. Maserat pertama disaring, kemudian dilakukan remaserasi berulang kali hingga bening. Maserat yang terkumpul kemudiaan diuapkan dengan vacum rotary evaporator pada suhu 50 으 kemudian diuapkan kembali dengan menggunakan waterbath hingga diperoleh ekstrak kental (Depkes RI, 2008).

3. Pembuatan fraksi dari ekstrak etanol 95\% daun kersen 
Ekstrak kental yang diperoleh sebanyak 750 gram. Sebanyak 25 gram ekstrak kental dilarutkan dalam $50 \mathrm{ml}$ etanol, $200 \mathrm{ml}$ air, dan $250 \mathrm{ml}$ n-heksana. Fraksinasi dilakukan menggunakan corong pisah, lalu digojok sehingga terbentuk 2 lapisan cairan yaitu fraksi $n$-heksana di bagian atas dan fraksi air di bagian bawah. Fraksi $n$-heksana yang didapat kemudian diuapkan sampai kental. Fraksi air difraksinasi kembali dalam corong pisah dengan etil asetat lalu digojok sehingga terbentuk 2 lapisan yaitu fraksi etil asetat pada bagian atas dan fraksi air pada bagian bawah. Fraksi etil asetat dan air yang didapat kemudian diuapkan sampai kental. Selanjutnya dilakukan pemeriksaan kadar air menggunakan metode destilasi serta perhitungan rendemen ekstrak kental dan perhitungan rendemen fraksi kental.

4. Penapisan fitokimia Larutan fraksi yang telah dilarutkan, ditotolkan dengan plat silika gel $\mathrm{GF}_{254}$ sebagai fase diam. Sistem fase gerak dan pereaksi semprot disesuaikan dengan masingmasing senyawa kimia yang akan diidentifikasi (Tabel 1).

Tabel 1. Penapisan fitokimia ekstrak dan fraksi daun kersen dengan metode KLT (Mauliandani et al., 2017; Harborne, 1987; Yanti et al., 2014)

\begin{tabular}{|c|c|c|c|c|}
\hline Senyawa & Fase Diam & Fase Gerak & Pereaksi & Hasil Positif \\
\hline Flavonoid & $\begin{array}{c}\text { Silika gel } \\
\mathrm{GF}_{254}\end{array}$ & $\begin{array}{c}n \text {-Heksana: Etil } \\
\text { asetat }(5: 5)\end{array}$ & Sitroborat & $\begin{array}{c}\text { Kuning-kehijauan dan } \\
\text { merah-kecoklatan }\end{array}$ \\
\hline Saponin & $\begin{array}{c}\text { Silika gel } \\
\mathrm{GF}_{254}\end{array}$ & $\begin{array}{c}\text { Kloroform : Metanol } \\
(10: 1)\end{array}$ & $\begin{array}{l}\text { Vanilin- } \\
\text { Asam Sulfat }\end{array}$ & $\begin{array}{l}\text { Biru hingga ungu biru } \\
\text { dan kekuningan }\end{array}$ \\
\hline Alkaloid & $\begin{array}{c}\text { Silika gel } \\
\mathrm{GF}_{254}\end{array}$ & $\begin{array}{c}\text { Kloroform : Metanol } \\
\qquad(9: 1)\end{array}$ & Dragendorff & Jingga-Coklat \\
\hline Tanin & $\begin{array}{l}\text { Silika gel } \\
\mathrm{GF}_{254}\end{array}$ & $\begin{array}{c}n \text {-Heksana: } \\
\text { Etil Asetat }(3: 7)\end{array}$ & Ferri Klorida & Biru \\
\hline Terpenoid & $\begin{array}{l}\text { Silika gel } \\
\mathrm{GF}_{254}\end{array}$ & $\begin{array}{l}\text { Kloroform : Metanol } \\
\qquad(10: 1)\end{array}$ & $\begin{array}{l}\text { Liebermann- } \\
\text { Burchard }\end{array}$ & Hijau-Coklat \\
\hline
\end{tabular}

5. Penentuan dosis fraksi

Dosis ekstrak daun kersen 50 $\mathrm{mg} / \mathrm{kgBB}$ dapat menghambat inflamasi sebesar $58,33 \%$ pada tikus putih jantan (Sarimanah et al., 2015). Maka pada penelitian ini, dosis fraksi 
yang akan digunakan didasarkan pada dosis ekstrak sebelumnya dengan menggunakan rendemen terkecil dari fraksi. Dengan demikian dosis fraksi yang digunakan pada penelitian ini adalah 5,13 mg/kgBB tikus.

Dosis $\mathrm{Na}$ diklofenak pada manusia adalah 100-150 mg/kgBB sehari terbagi dua atau 3 dosis (Sulistia dan Freedy, 2016). Perhitungan dosis dikonversikan dari manusia ke tikus berdasarkan rumus Food and Drug Administration (FDA) sehingga diperoleh dosis $\mathrm{Na}$ diklofenak 10,278 mg/kgBB.

6. Penentuan dosis Na diklofenak

Dosis $\mathrm{Na}$ diklofenak pada manusia adalah 100-150 mg/kgBB, sehari terbagi dua atau 3 dosis (Sulistia dan Freedy, 2016). Perhitungan dosis dikonversikan dari manusia ke tikus berdasarkan rumus Food and Drug Administration (FDA) sehingga diperoleh dosis $\mathrm{Na}$ diklofenak 10,278 mg/kgBB.

7. Pembuatan sediaan uji fraksi daun kersen

Fraksi daun kersen ditimbang, kemudian ditambahkan $\mathrm{Na}$ CMC secukupnya dan digerus sampai homogen hingga terbentuk suspensi.
8. Pembuatan sediaan suspensi $\mathrm{Na}$ diklofenak sebagai pembanding

$\mathrm{Na}$ diklofenak ditimbang sebanyak 0,01 gram lalu dilarutkan dalam suspensi $\mathrm{Na}$ CMC sebanyak 5 $\mathrm{ml}$.

9. Pembuatan larutan $\mathrm{PBS}$ pH 7,4

$\mathrm{NaH}_{2} \mathrm{PO}_{4}$ sebanyak 6,9 gram dilarutkan dalam $250 \mathrm{ml}$ aqua bebas $\mathrm{CO}_{2}, \mathrm{Na}_{2} \mathrm{HPO}_{4}$ sebanyak 7 gram dilarutkan dalam $250 \mathrm{ml}$ aqua bebas $\mathrm{CO}_{2}, 19 \mathrm{ml} \mathrm{NaH}_{2} \mathrm{PO}_{4}$ diambil dan $\mathrm{Na}_{2} \mathrm{HPO}_{4}$ sebanyak $80 \mathrm{ml}$ kemudian dimasukkan ke dalam beaker glass lalu ad $200 \mathrm{ml}$ dengan aqua bebas $\mathrm{CO}_{2}$ (Departemen Kesehatan RI, 1995).

10. Pembuatan larutan karagenin $2 \%$

Sebanyak 500 mg karagenin dimasukkan ke dalam mortir, dilarutkan sedikit demi sedikit dengan $\mathrm{NaCl} 0,9 \%$ hangat sekitar $90 \stackrel{\circ}{\circ}$ kemudian dicukupkan dalam $25 \mathrm{ml}$ untuk satu kelompok tikus (Duarte et al., 2016).

11. Persiapan hewan uji

Penelitian ini telah mendapatkan persetujuan etik dengan nomor 02/18.05/011 oleh Komisi Etik Penelitian Kesehatan Universitas Muhammadiyah Prof. Dr. Hamka (KEPK-UHAMKA). 
Tahap awal persiapan hewan uji adalah aklimatisasi. Aklimatisasi bertujuan untuk menyeragamkan cara hidup dan makanan hewan uji yang digunakan dalam penelitian. Hewan uji diaklimatisasi selama 7 hari. Selama masa aklimatisasi, hewan uji diberikan makan dan minum sesuai standar serta dilakukan pemeriksaan kesehatan fisik berupa penimbangan berat badan. Setelah 7 hari, masing-masing tikus dibagi dalam 5 kelompok dan masingmasing kelompok terdiri dari 4 ekor tikus.

12. Pengujian efek antiinflamasi dengan metode granuloma pouch

Hari pertama, bulu tengkuk (di antara scapula) tikus dicukur dan dioleskan krim pencukur rambut. Tikus dianestesi menggunakan ketamin secara intramuscular (im). Selanjutnya daerah tengkuk yang sudah dicukur, diusap dengan etanol $70 \%$ dan diinjeksikan udara steril \pm 20 ml menggunakan needle 23 G. Tiga hari kemudian hewan dianestesi kembali dengan ketamin secara im, kemudian punggung tikus diusap dengan etanol $70 \%$ dan diinjeksikan $10 \mathrm{~mL}$ udara secara subkutan untuk membuat kantung udara. Hari keenam, setelah penyuntikan udara kelompok hewan percobaan masingmasing diberikan zat uji sebagai berikut: kelompok kontrol negatif diberikan $\mathrm{Na} \mathrm{CMC} \quad 0,5 \%$ peroral, kelompok kontrol positif diberikan $\mathrm{Na}$ diklofenak 10,278 mg/kgBB peroral, dan kelompok uji masing-masing diberikan fraksi $n$-heksana, fraksi etil asetat, serta fraksi air secara peroral dengan dosis 5,13 mg/kgBB tikus. Satu jam kemudian semua hewan dianestesi kembali dengan ketamin secara im dan diinduksi inflamasi dengan cara menyuntikan $5 \mathrm{~mL}$ larutan karagenin $2 \%$ ke dalam kantung udara menggunakan syringe $5 \mathrm{ml}$. Eksudat dalam kantung diambil 24 jam setelah induksi inflamasi. Pengambilan eksudat dilakukan dengan cara menggunting kantung secara vertikal $( \pm 2 \mathrm{~cm})$. Eksudat dikumpulkan dengan menggunakan pipet dan dimasukkan ke dalam tube steril (Duarte et al., 2016). Volume eksudat diukur dan dihitung persentase penghambatan pembentukan eksudatnya (Duarte et al., 2016). Selanjutnya eksudat diisap dengan pipet thoma leukosit sampai tanda 0,5 pada pipet, kemudian diisap larutan pengencer $(\mathrm{NaCl} 0,9 \%)$ 
sampai tanda 11 (pengencer 1:20) pada pipet thoma. Pipet thoma leukosit tersebut dipegang sedemikian rupa sehingga kedua ujung pipet terletak di antara ibu jari dan telunjuk tangan kanan kemudian dihomogenkan selama 3 menit. Sebelum pengisian kamar hitung, dibuang 4 tetes pertama eksudat dan ujung pipet diletakkan pada kamar hitung (improved neubauer) tepat batas kaca penutup (cover glass). Eksudat diisikan ke dalam kamar hitung tersebut pada tetesan yang ke 5. Kamar hitung setelah diisi eksudat dibiarkan selama 3 menit lalu dihitung jumlah leukosit total pada mikroskop dengan perbesaran $40 \times 10$ (Gandasobrata, 2010). Jumlah leukosit total ditentukan dengan rumus berikut:

$$
\text { Jumlah Leukosit Total }=\frac{N \times 20}{0,4}
$$

Keterangan:

$\mathrm{N}=$ Jumlah leukosit dalam ke-4 bidang besar

$20=$ Faktor pengenceran

$0,4=$ Volume yang dihitung

\section{Analisis data}

Data volume eksudat dan jumlah leukosit total dianalisis secara statistik. Data-data tersebut diuji normalitas dan homogenitasnya. Jika data terdistribusi normal dan homogen maka analisis data dilanjutkan dengan uji Analysis of Variance (ANOVA) satu arah dengan taraf signifikansi $95 \%(\alpha=0,05)$. Jika terdapat perbedaan yang bermakna maka dilanjutkan dengan uji Tukey HSD.

\section{Hasil dan Pembahasan}

Hasil Pembuatan Ekstrak dan Fraksi Daun Kersen

Hasil ekstraksi dan fraksinasi daun kersen dapat dilihat pada Tabel 2 . Proses ekstraksi daun kersen menghasilkan ekstrak etanol 95\% dengan persentase rendemen terhadap simplisia yang diekstraksi sebesar $27,84 \%$. Sedangkan rendemen hasil fraksi $n$-heksana, etil asetat, dan air secara berturut-turut sebesar 18,50; 10,26; dan $28,09 \%$.

Hasil Pemeriksaan Kandungan Kimia Ekstrak dan Fraksi Daun Kersen dengan Metode KLT

Penapisan fitokimia dilakukan untuk mengetahui kandungan senyawa yang terkandung di dalam ekstrak dan fraksi. Senyawa yang diidentifikasi meliputi flavonoid, saponin, terpenoid, tanin, dan alkaloid. Penapisan fitokimia dilakukan dengan metode kromatografi 
lapis tipis (KLT) menggunakan fase diam silika gel $\mathrm{GF}_{254}$ dan berbagai macam fase gerak. Pemisahan yang terjadi pada KLT berdasarkan pada mekanisme adsorpsi dan partisi. Tujuan dilakukan uji penapisan fitokimia dengan metode KLT adalah untuk memastikan bahwa senyawa aktif benar berada di dalam ekstrak dan fraksi. Pada umumnya, KLT lebih banyak digunakan untuk tujuan pemisahan, namun juga dapat digunakan untuk tujuan identifikasi karena metode ini relatif mudah, sederhana, dan memberikan pilihan fase gerak yang lebih beragam (Hanani, 2016).

Hasil pemeriksaan kandungan kimia ekstrak dan fraksi dapat dilihat pada Tabel 3. Berdasarkan hasil yang diperoleh, flavonoid, saponin, dan terpenoid terkandung di dalam ekstrak, fraksi $n$-heksana, dan fraksi etil asetat. Alkaloid terkandung di dalam ekstrak dan semua jenis fraksi daun kersen. Sedangkan tanin terkandung di dalam ekstrak, fraksi etil asetat, dan fraksi air.

Tabel 2. Hasil ekstraksi dan fraksinasi daun kersen

\begin{tabular}{cccc}
\hline No & Jenis & Hasil (g) & Rendemen (\%) \\
\hline 1 & Ekstrak & 751,8 & 27,84 \\
2 & Fraksi n-Heksana & 46,9 & 18,50 \\
3 & Fraksi Etil Asetat & 26 & 10,26 \\
4 & Fraksi Air & 71,2 & 28,09 \\
\hline
\end{tabular}

Tabel 3. Hasil penapisan fitokimia dengan metode KLT

\begin{tabular}{lcccc}
\hline Senyawa & $\begin{array}{c}\text { Ekstrak } \\
\text { Etanol }\end{array}$ & $\begin{array}{c}\text { Fraksi } \\
\boldsymbol{n} \text {-Heksana }\end{array}$ & $\begin{array}{c}\text { Fraksi } \\
\text { Etil Asetat }\end{array}$ & Fraksi Air \\
\hline Flavonoid & $(+)$ & $(+)$ & $(+)$ & $(-)$ \\
Saponin & $(+)$ & $(+)$ & $(+)$ & $(-)$ \\
Alkaloid & $(+)$ & $(+)$ & $(+)$ & $(+)$ \\
Tanin & $(+)$ & $(-)$ & $(+)$ & $(+)$ \\
Terpenoid & $(+)$ & $(+)$ & $(+)$ & $(-)$ \\
\hline
\end{tabular}

Keterangan:

(+) : mengandung senyawa yang dideteksi

(-) : tidak mengandung senyawa yang dideteksi 
Hasil Pengukuran Volume Eksudat dan Perhitungan Persentase Penghambatan Pembentukan Eksudat

Eksudat pada kantung granuloma masing-masing tikus diambil menggunakan spuit dan diukur volumenya. Volume eksudat masingmasing kelompok dirata-rata dan

$$
\begin{array}{lrr}
\text { dilanjutkan dengan } & \text { menghitung } \\
\text { persentase } & \text { penghambatan }
\end{array}
$$

pembentukan eksudat. Data rerata volume eksudat dan persentase penghambatan pembentukan eksudat dapat dilihat pada Tabel 4 dan Gambar 1.

Tabel 4. Rerata volume eksudat dan persentase penghambatan pembentukan eksudat

\begin{tabular}{lcc}
\hline Kelompok & Rerata Volume Eksudat (ml) & $\begin{array}{c}\text { Persentase Penghambatan } \\
\text { Pembentukan Eksudat(\%) }\end{array}$ \\
\hline Kontrol Negatif & 2,48 & \\
Kontrol Positif & 0,88 & 64,52 \\
Fraksi $n$-Heksana & 1,68 & 32,26 \\
Fraksi Etil Asetat & 1,2 & 51,61 \\
Fraksi Air & 1,72 & 30,65 \\
\hline
\end{tabular}

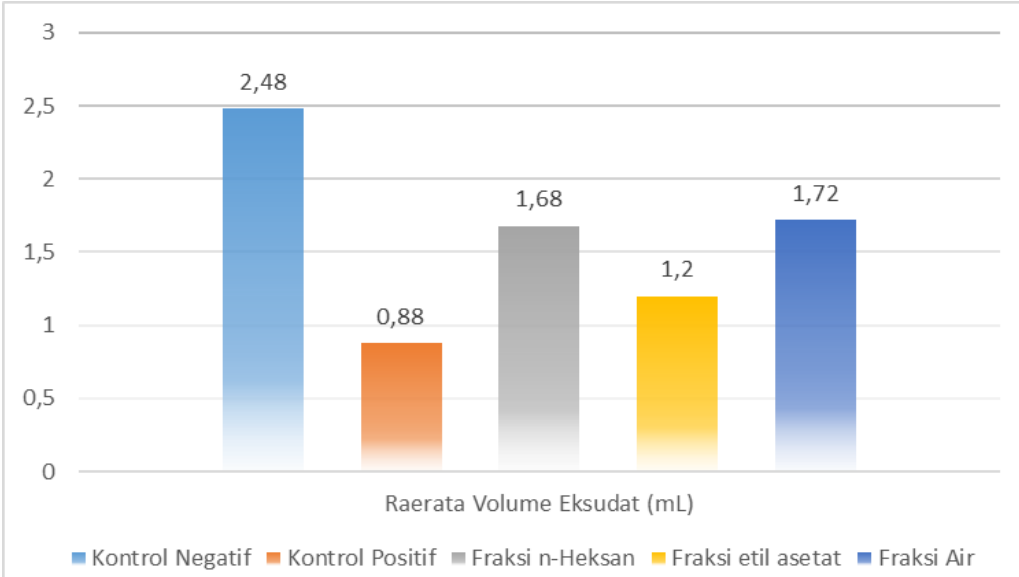

Gambar 1. Rerata volume eksudat.

Rerata volume eksudat heksana, etil asetat, dan air masingkelompok kontrol negatif adalah 2,48 ml, masing sebesar 1,68; 1,20; dan 1,72 ml. kelompok kontrol positif sebesar 0,88 Hasil ini menunjukkan bahwa terdapat $\mathrm{ml}$, sedangkan kelompok fraksi $n$ - penurunan volume eksudat pada 
masing-masing kelompok yang diberikan fraksi daun kersen dibandingkan kelompok kontrol negatif yang hanya diberikan $\mathrm{Na}$ CMC saja.

Persentase penghambatan pembentukan eksudat kelompok kontrol positif diperoleh sebesar 64,52\%; fraksi $n$-heksana sebesar 32,26\%; fraksi etil asetat 51,61\%; dan fraksi air sebesar $30,65 \%$. Suatu bahan dikatakan memiliki daya antiinflamasi jika hewan uji yang diinduksi karagenin mengalami pengurangan pembekakan (persentase penghambatan radang) sebesar $50 \%$ atau lebih (Mansjoer, 1997). Hasil penelitian yang dilakukan menunjukkan bahwa masing-masing fraksi memiliki potensi sebagai antiinflamasi namun hanya fraksi etil asetat yang memiliki persentase penghambatan pembentukan eksudat lebih dari 50\%.

Data volume eksudat yang diperoleh selanjutnya dianalisis secara statistik. Hasil analisis data volume eksudat menyatakan bahwa data terdistribusi normal $(\rho=0,195)$ dan homogen $(\rho=0,960)$. Data selanjutnya dianalisis secara statistika menggunakan ANOVA satu arah. Hasil uji data volume eksudat menunjukkan nilai $\rho=0,000$ yang berarti bahwa terdapat perbedaan yang bermakna antar kelompok. Hasil uji
Tukey HSD menunjukkan bahwa kelompok fraksi air, $n$-heksana, dan fraksi etil asetat berbeda bermakna dengan kelompok kontrol negatif $(p<0,05)$. Akan tetapi hanya fraksi etil asetat yang sebanding dengan kontrol positif $(p=0,284)$. Hasil ini menunjukkan bahwa ketiga fraksi daun kersen memiliki efek antiinflamasi karena berbeda bermakna dengan kelompok kontrol negatif. Namun yang lebih efektif adalah kelompok fraksi etil asetat karena volume eksudat yang terbentuk lebih sedikit dibandingkan kelompok fraksi lain dan secara statistik sebanding dengan kontrol positif.

Hasil Perhitungan Jumlah Leukosit Total Hasil perhitungan jumlah leukosit total dapat dilihat pada Tabel 5 dan Gambar 2. Rerata jumlah leukosit total pada kelompok kontrol negatif sebesar 43.000/ $\mu \mathrm{L}$ eksudat, kontrol positif sebesar $19.780 / \mu \mathrm{L}$ eksudat, fraksi

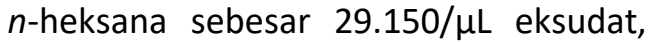
etil asetat sebesar $22.880 / \mu \mathrm{L}$ eksudat, sedangkan fraksi air 30.430/ $\mathrm{L}$ L eksudat. Hasil ini menunjukkan bahwa pemberian fraksi daun kersen mampu menurunkan jumlah sel leukosit. Penurunan jumlah sel leukosit pada eksudat merupakan salah satu tanda pemulihan inflamasi. 
Data jumlah leukosit total yang diperoleh, dianalisis secara statistik. Analisis statistik dimulai dengan uji Kolmogorov-Smirnov. Hasil analisis data yang diperoleh pada jumlah leukosit total menyatakan bahwa data terdistribusi normal dengan nilai $p=0,200$ dan homogen dengan nilai $p=0,215$. Setelah data yang diperoleh terdistribusi normal dan homogen kemudian diuji secara statistika menggunakan ANOVA satu arah. Hasil uji data jumlah leukosit total menunjukkan nilai $p=0,000$. Hasil ini menunjukkan adanya perbedaan bermakna. Hasil dari uji Tukey HSD menunjukkan bahwa fraksi $n$-heksana, fraksi etil asetat, dan fraksi air memiliki perbedaan bermakna dengan kontrol negatif $(p<0,05)$. Akan tetapi yang paling baik efek antiinflamasinya ialah fraksi etil asetat karena fraksi etil asetat memiliki efek yang sebanding dengan kontrol positif dalam menurunkan jumlah leukosit total.

Tabel 5. Rerata jumlah leukosit total eksudat

\begin{tabular}{lc}
\hline Kelompok & Rerata Jumlah Leukosit Total/ $\mu$ L Eksudat \\
\hline Kontrol Negatif & 43.000 \\
Kontrol Positif & 19.780 \\
Fraksi n-Heksana & 29.150 \\
Fraksi Etil Asetat & 22.800 \\
Fraksi Air & 30.430 \\
\hline
\end{tabular}

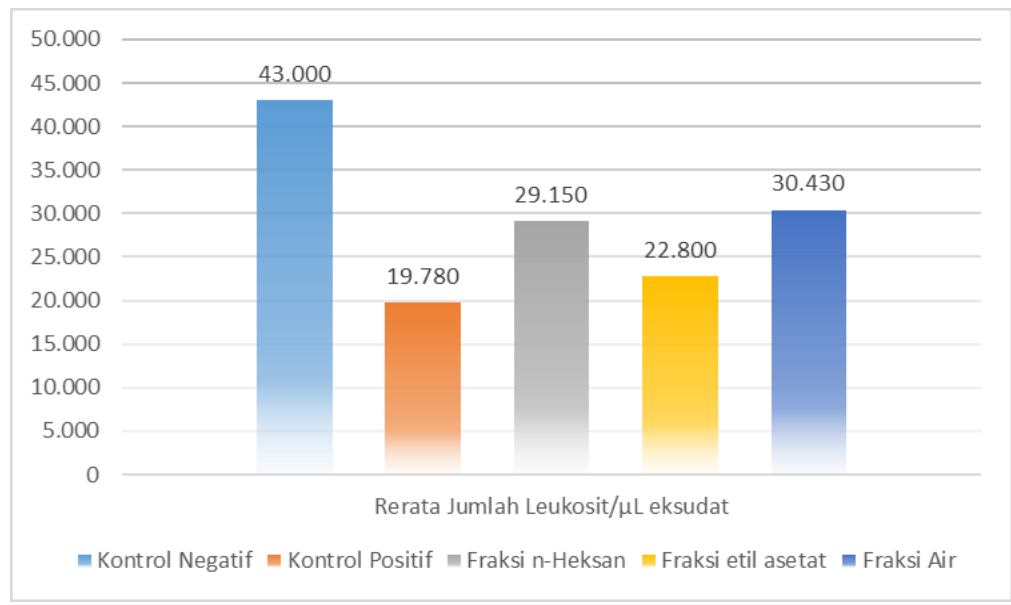

Gambar 2. Rerata jumlah leukosit eksudat. 
Hasil penelitian efek antiinflamasi dengan parameter penurunan volume eksudat dan sel leukosit eksudat yang telah dilakukan menunjukkan bahwa efek antiinflamasi fraksi etil asetat lebih baik dibandingkan fraksi lain. Hasil penapisan fitokimia daun kersen dengan metode KLT pada penelitian ini menunjukkan bahwa fraksi etil asetat mengandung senyawa flavonoid, tanin, saponin, alkaloid, terpenoid. Penelitian Yusof et al. (2013) menyimpulkan bahwa daun kersen mengandung senyawa seperti flavonoid, tanin, alkaloid, saponin, terpenoid, dan steroid yang berefek sebagai antiinflamasi. Mekanisme senyawa flavonoid sebagai senyawa antiinflamasi adalah melalui beberapa jalur seperti melalui penghambatan degranulasi neutrofil, penghambatan aktivitas enzim siklooksigenase (COX), dan lipooksigenase sehingga tidak terbentuk prostaglandin yang merupakan mediator inflamasi (Khotimah dan Muhtadi, 2015). Senyawa saponin mampu berinteraksi dengan banyak membran lipid seperti fosfolipid yang merupakan prekursor prostaglandin dan mediator-mediator inflamasi lainnya (Hidayati et al., 2008). Senyawa alkaloid dapat memiliki efek antiinflamasi dengan menekan pelepasan histamin oleh sel mast, mengurangi sekresi interleukin-1 oleh monosit dan PAF pada platelet (Luliana et al., 2017). Terpenoid secara umum bekerja melalui penghambatan enzim fosfolipase melalui jalur asam arakhidonat. Terhambatnya enzim fosfolipase menyebabkan pembentukan asam arakhidonat dari fosfolipid juga terhambat (Zaini et al., 2016). Tanin berperan sebagai antiinflamasi dengan berbagai cara yaitu menghambat produksi oksidan oleh neutrofil, monosit, dan makrofag (Sukmawati et al., 2015).

\section{Simpulan}

Berdasarkan pengujian yang telah dilakukan dapat disimpulkan bahwa fraksi ekstrak etanol 95\% daun kersen memiliki efek antiinflamasi dengan parameter volume eksudat dan jumlah leukosit total. Hanya fraksi etil asetat yang memiliki persentase penghambatan eksudat lebih dari 50\% dan jumlah volume eksudat serta jumlah leukosit total sebanding dengan kontrol positif.

\section{Daftar Pustaka}

Departemen Kesehatan RI. 2008. Farmakope Herbal Indonesia. 
Jakarta: Direktorat Jenderal Pengawasan Obat dan Makanan.

Departemen Kesehatan RI. 1995. Farmakope Indonesia. Edisi 4. Jakarta: Direktorat Jenderal Pengawasan Obat dan Makanan.

Duarte, D.B., Vasko, M.R., and Fehrenbacher, J.C. 2016. Models of inflammation: Carrageenan Air Pouch. Current Protocols in Pharmacology, 72:5.6.1-5.6.9.

Furst, D.E., Urlich, R.W. \& Prakash, S. 2013. Anti-inflamasi Non-steroid Antirematik, Pemodifikasi Penyakit, Analgetik Non-opioid, \& untuk Gout. Dalam: Katzung, B.G. Farmakologi Dasar \& Klinik. Edisi 12 Vol. 2. Jakarta: EGC.

Gandasoebrata, R. 2010. Penuntun Laboratorium Klinik. Edisi 16. Jakarta: Dian Rakyat.

Hanani, E. 2015. Analisis Fitokimia. Jakarta: EGC.

Harborne, J.B. 1987. Metode Fitokimia Penuntun Cara Modern Menganalisis Tumbuhan. Edisi ke2. Bandung: ITB.

Hidayati, N.A., Listyawati, S., dan Setyawan, A.D. 2008. Kandungan kimia dan uji antiinflamasi ekstrak etanol Lantana camara L. pada tikus putih (Rattus norvegicus L.) jantan. Bioteknologi, 5(1):10-17.

Khotimah, S.N. dan Muhtadi, A. 2015. Beberapa tumbuhan yang mengandung senyawa aktif antiinflamasi. Farmaka, 14(2):2840.
Luliana, S., Susanti, R., dan Agustina, E. 2017. Uji aktivitas antiinflamasi ekstrak air herba ciplukan (Physalis angulata L.) terhadap tikus putih (Rattus norvegicus L.) jantan galur wistar yang diinduksi karagenan. Traditional Medicine Journal, 22(3):199-205.

Kuo, W.L., Liao, H.R., Chen, J.J. 2014. Biflavans, flavonoids and a dihydrochalcone from the stem wood of Muntingia calabura and their inhibitory activities on neutrophil pro-inflammatory responses. Molecules, 19: 2052120535.

Mahmood, N.D., Nasir, N.L., Rofiee, M.S., Tohid, S.F., Ching, S.M., Teh L.K., Saleh, M.Z., and Zakaria, Z.A. 2014. Muntingia calabura: a review of its traditional uses, chemical properties, and pharmacological observations. Pharmaceutical Biology, 52(12):1598-1623.

Mansjoer, S. 1997. Efek antiradang minyak atsiri temu putih (Curcuma zeddoria Rosc) terhadap udem buatan pada tikus utih betina jaur wistar. Majalah Farmasi Indonesia, 8:35-41.

Mauliandani, N., Lukmayani, Y., Sadiyah, E.R. 2017. Isolasi dan identifikasi senyawa flavonoid yang berpotensi sebagai antioksidan dari herba bayam merah (Amaranthus tricolor L.). Prosiding Seminar Penelitian Sivitas Akademika Unisba, 15-16 Agustus 2016, Universitas Islam Bandung.

Nurdin, A., Priyanto, dan Rini, P. 2016. Antiinflamasi topikal ekstrak daun kersen (Muntingia calabura L.) 
dengan parameter penurunan jumlah leukosit dan monosit pada tikus putih jantan. Skripsi. Universitas Muhammadiyah Prof. Dr. Hamka.

Sarimanah, J., Adnyana, K., Yulinah, E., dan Kurniati, N.F. 2015. Anti inflammatory activities of unripe, ripe Muntingia calabura L. fruits and Muntingia calabura L. leaves in wistar white rat. Proceedings The $1^{\text {st }}$ University Research Colloquium (URECOL), 24 Januari 2014, Universitas Muhammadiyah Surakarta.

Sukmawati, Yuliete, dan Hardani, R. 2015. Uji aktivitas antiinflamasi ekstrak etanol daun pisang ambon (Musa paradisiaca L.) terhadap tikus putih (Rattus norvegicus L.) yang diinduksi karagenan. Jurnal Farmasi Galenika, 1(2):126-132.

Sulistia, G. dan Freedy, W.P. 2016. Analgesik-Antipiretik Analgesik Antiinflamasi Nonsteroid dan Obat
Gangguan Sendi Lainnya. Dalam: Gan, S.G. Farmakologi dan Terapi. Edisi 6. Jakarta: FKUI.

Yanti, M. 2014. Isolasi dan identifikasi senyawa alkaloid dalam ekstrak daun sirsak hutan (Annoa glabra). Skripsi. Fakultas MIPA, Institut Pertanian Bogor.

Yusof, M.I.M., Salleh, M.Z., Kek, T.L., Ahmat, N., Azmin, N.F.N., and Zakaria, Z.A. 2013. Activity guided isolation of bioactive constituents with antinociceptive activity from Muntingia calabura L. leaves using the formalin test. Evidence-Based Complementary and Alternative Medicine, 2013:Article ID 715074.

Zaini, M., Biworo, A., dan Anwar, K. 2016. Uji efek antiinflamasi ekstrak etanol herba lampasau (Diplazium esculentum Swartz) terhadap mencit jantan yang diinduksi karagenin- $\Lambda$. Jurnal Pharmascience, 3(2):119-130. 